\title{
Kouluttamiseen liittyvän pätevyyden kehittämisestä
}

\author{
Pekka Antila \& Heljä Hätönen
}

\author{
Aikuiskasvattajan työtä tekevät monet sellaiset henkilöt, \\ jotka eivät ole ammatiltaan aikuiskasvattajia ja joiden \\ päätehtävä on muu kuin koulutus tai kehittäminen. \\ Monet heistä ovat oppineet aikuiskasvattajan työhön \\ käytännön kautta. Myös he hyötyvät pedagogisen \\ pätevyytensä kehittämisestä. Yhden esimerkin \\ osaamisen lisäämisestä antaa Educa-Instituutti Oy:n \\ Kouluttamisen ajokortti -koulutusohjelma.
}

$\mathrm{T}$ oisen ihmisen ohjaamista, opastusta ja koulutusta edellyttävät tilanteet lisääntyvät työelämässä jatkuvasti. Tähän on merkittävästi vaikuttamassa mm. muuttunut toisen asteen ammatillinen peruskoulutus, johon sisältyy mittava, vähintään 20 opintoviikon laajuinen, työpaikoilla suoritettava työssäoppimiskokonaisuus. Työssäoppiminen tarkoittaa käytännössä sitä, että osa tutkinnon tavoitteista opitaan opetussuunnitelman mukaisesti työpaikoilla (Opetushallitus 1999). Ammatin edellyttämät tiedot ja taidot opitaan siis yhä useammin todellisissa työtilanteissa aidossa työympäristössä ja ohjaajina toimivat kokeneet työntekijät.

Myös henkilöstökoulutuksen määrä lisääntyy. Tilastokeskuksen uusimpien julkaistujen tietojen mukaan vuosien 1995 ja 2000 välillä henkilöstökoulutukseen osallistuneiden palkansaajien määrä kasvoi 15 prosenttiyksikköä, likipitäen samaan tahtiin palkansaajien määrän lisääntymisen kanssa. (Tilastokeskus 2002.) Henkilöstökoulutuksessa kouluttajina toimivat useimmiten alan asiantuntijat, joilta usein puuttuu pedagoginen pätevyys. Työpaikoilla tapahtuvan koulutuksen määrää arvioitaessa on lisäksi huomioitava se, että viime vuosina henkilöstön kehittämisen suuntaus on ollut kohti työn ohessa oppimista, joka ei näy kurssimuotoisen henkilöstökoulutuksen kehitystä kuvaavissa tilastoissa (Valkeavaara 1998). Tällaisissa tilanteissa oppimisen ohjaajina toimivat työtoverit, esimiehet ja sisäiset kehittäjät.

Jotta henkilöstökoulutus, työssäoppimisen ohjaus ja muu ihmisten erilaisiin elämänpiireihin (esim. järjestötyö) liittyvä koulutus olisi mahdollisimman laadukasta, on perusteltua huolehtia myös näissä oppilaitosten ulkopuolella olevissa erilaisissa koulutus- ja ohjaustehtävissä toimivien henkilöiden didaktisen perusosaamisen ja oppimisen ohjaustaitojen kehittämisestä.

\section{Väyliä pedagogisen pätevyyden kehittämiseen}

Oppir ppilaitosten virantäytössä edellyttämän pedagogisen pätevyyden saa suorittamalla 35 opintoviikon laajuiset kasvatustieteelliset opettajan pedagogiset opinnot. Monimuotokoulutuksenakin toteutettuna näin laajat opinnot ovat monelle työssäkäyvälle liian raskas vaihtoehto. Työpaikkaohjaajille on luotu kahden opintoviikon laajuinen koulutusohjelma (Opetushallitus), jonka toteutuksesta on saatu myönteisiä kokemuksia. Kyseinen koulutus on suunnattu työssä- 
oppimisjaksojen opiskelijoiden ohjaajille. Yksittäiset, useimmiten 1-3 päivän mittaiset eri organisaatioiden järjestämät kouluttajan valmiuksia kehittävät kurssit antavat alkupotkua kouluttamiseen, mutta ne voivat jäädä liian suppeiksi kehitettäessä syvällisempää pedagogista osaamista.

Educa-Instituutissa kehitetty kuuden opintoviikon laajuinen Kouluttamisen ajokortti -koulutusohjelma on luotu näiden eri kouluttautumismuotojen rinnalle pedagogisessa koulutustarjonnassa. Tietokoneen ajokortti -idean laajentaminen kouluttajakoulutukseen syntyi Kari Kaipaisen (2000) ja Educa-Instituutti Oy:n yhteistyönä. Ajokortti-ideaa koulutusohjelma toteuttaa tarjoamalla joustavan ja kaikille avoimen vaihtoehdon kouluttamisessa tarvittavien monipuolisten käytännön perustaitojen hankkimiseen.

\section{Kokemuksia Kouluttamisen ajokortti -koulutusohjelmasta}

$\mathrm{K}_{\mathrm{s}}$ ouluttamisen ajokortti -koulutusohjelma muodostuu seuraavista kuudesta 1-2 opintoviikon laajuisesta opintojaksosta: kouluttamisen perusteet, opetuksen ja koulutuksen suunnittelu, henkilöstökoulutuksen suunnittelu ja toteutus, koulutuksen toteutus, palaute ja arviointi koulutuksessa sekä kouluttamisen ohjausryhmä. Myös yksittäisiin opintojaksoihin osallistuminen on mahdollista. Opintojaksoihin kuuluu lähipäivien lisäksi ennakkotehtäviä, kirjallisuuden lukemista sekä välitehtävä, useimmiten myös jälkitehtävä. Kouluttamisen ohjausryhmään osallistuminen on mahdollistanut syventymisen osallistujien valitsemiin aiheisiin ja toiminut myös pidettynä verkostoitumisfoorumina.

Ensimmäisellä koulutusohjelman toteutuskierroksella kullekin opintojaksolle osallistui 815 henkilöä. Koko Kouluttamisen ajokortti -koulutusohjelman ensimmäisinä suorittaneet viisi henkilöä haastateltiin.

Koko koulutusohjelman suorittaneet henkilöt työskentelevät sekä yksityisellä että julkisella sektorilla erilaisissa suunnittelijan, koulutuspäällikön ja henkilöstönkehittämisen asiantuntijan tehtävissä. Kouluttamiseen liittyvät tehtävät muodostavat heidän työstään oman arvionsa mukaan ainakin välillisesti noin 20-100 prosenttia. Osalla koulutusohjelmaan osallistuneista oli taustalla jo pitkä kouluttamiseen liittyvä työkokemus, osa oli vasta siirtynyt koulutustehtäviin.

Haastatellut henkilöt kertoivat kiinnittävänsä koulutusohjelmaan osallistuttuaan omassa työssään aikaisempaa enemmän huomiota koulutuksen kokonaissuunnitteluun sekä erityisesti koulutuksen tavoitteellisuuteen. Koulutuksen suunnitteluun liittyen eräs haastateltava oli oivaltanut eri oppimisnäkemysten erilaiset pedagogiset seuraukset; opetus voidaan muuttaa oppijalähtöiseksi pienelläkin toteutustavan muutoksella. Eräs haastatelluista puolestaan havaitsi koulutusohjelman aikana tavoitteellisuuden erityisen tärkeän merkityksen omassa organisaatiossaan - ja henkilöstökoulutuksessa yleisemminkin - tyypillisissä koulutustilaisuuksissa, joissa useat eri asiantuntija-kouluttajat valmistelevat ja toteuttavat omat osuutensa itsenäisesti. Haastateltavat suhtautuvat koulutusohjelman suoritettuaan kriittisemmin myös tavoitteiden toteutumiseen.

Koulutusta koskevaa palautetta kerättäessä kerrottiin kiinnitettävän aikaisempaa enemmän huomiota siihen, mitä tietoa osallistujilta kannattaa kerätä. Osallistujat aikovat jatkossa kerätä tietoa erityisesti siitä, miten heidän koulutuksiinsa osallistuneet aikovat soveltaa koulutuksen sisältöjä käytäntöön. Koulutusohjelmassa keskeisesti esillä olleet aktivoivat opetusmenetelmät olivat siirtyneet käytäntöön useimpien haastateltujen työssä jo koulutusohjelman aikana.

\section{Koulut t a misen asiantuntijuden ydin}

凹aastattelemamme Kouluttamisen ajokortti- koulutusohjelman suorittaneet henkilöt pitivät kouluttamiseen liittyvissä tehtävissään tärkeimpinä osaamisina seuraavia:

- pedagoginen osaaminen; kouluttamisen kokonaisprosessin hallinta, johon sisältyy opetusja arviointimenetelmien hallinta sekä kyky käyttää niitä tilanteen vaatimusten mukaan

- vuorovaikutus- ja vaikuttamistaidot

- koulutuksen kohderyhmän ja sen tarpeiden tunteminen

- koulutuksen sisällön tuntemus

- kyky toimia niin, että ihmisten asiantuntemus pääsee esiin 
- kyky muuttaa omaa ohjaajan roolia tilanteen vaatimusten mukaan

- sen ymmärtäminen, että ihmiset ovat erilaisia oppijoita

- aikuisen oppimisen erityispiirteiden ymmärtäminen

- ihmistuntemus

- kokous-, neuvottelu- ja viestintätaidot

- johtamistaidot ja markkinointiosaaminen

Edellä mainittuja koulutusohjelman suorittaneiden määrittelemiä osaamisalueita voidaan verrata esimerkinomaisesti opettajan tiedonalueita koskevaan tutkimustietoon. Usein viitatussa artikkelissaan Schulman (1987) määrittelee opettajan tiedonalueiksi seuraavat:

- sisältötieto

- yleinen pedagoginen tieto koskien erityises ti oppilasryhmän hallintaa

- opetussuunnitelmatieto

- pedagoginen sisältötieto

- tieto oppijoista

- tieto toimintaympäristöstä

- tieto opetuksen päämääristä ja arvoista sekä niiden historiallisista ja filosofisista taustoista

Listojen pikainenkin silmäily osoittaa selviä yhtäläisyyksiä. Molemmissa listoissa esiintyy pedagoginen osaaminen, vuorovaikutus oppijoiden kanssa sekä koulutuksen sisällön ja kohderyhmän tunteminen. Haastattelemamme henkilöt mainitsivat lisäksi sellaisia selvästi toimintaympäristösidonnaisia seikkoja, kuten markkinointiosaaminen, jotka eivät useimmiten ole yhtä relevantteja oppilaitosympäristössä. Schulmanin (emt.) listassa puolestaan viitataan opetussuunnitelmaan sekä koulutuksen päämäärien ja arvojen historiallisiin ja filosofisiin taustoihin, jotka työelämän organisaatiossa korvautuvat tavallisesti kyseisen organisaation tavoitteilla ja arvoilla. Sama opetus-oppimisprosessin ydin - kohderyhmän ja sisällön tunteminen, toimiva vuorovaikutus oppijoiden kanssa sekä erityinen pedagoginen osaaminen - pätee siis niin opettajan kuin kouluttajankin työssä.

Helakorven (1999) mukaan kouluttajan ammattitaito perustuu teoreettisesti hallittuun opetustyöhön, johon opetuksen lisäksi kuuluu myös oman työn ja koko organisaation yhteistyö ja kehittäminen. Hän ehdottaa kouluttajan asiantuntijuuden muodostuvan substanssiosaamisesta, pedagogisesta osaamisesta, tieteellisestä (kehittämis-) osaamisesta sekä organisaatio-osaamisesta. Kouluttamisen ajokortti -koulutusohjelmaan on pyritty tiiviisti sisällyttämään kouluttamisessa tarvittavat perusvalmiudet, joten Helakorven ehdottamista asiantuntijuuden osa-alueista koulutusohjelma tukee ensisijaisesti pedagogisen osaamisen kehittymistä.

\section{Lopuksi}

\äytännön koulutustyön tuomalla kokemuksella on kiistämätön arvonsa, mutta ollakseen laadukasta kouluttamiseen liittyvän osaamisen kehittämisen on perustuttava myös opetusoppimisprosessista saatavilla olevaan tutkittuun tietoon. Kouluttamiseen liittyvää pätevyyttä kehitettäessä ei ole mitään perusteita olla nojautumatta samoihin didaktisiin periaatteisiin, joihin perustuu myös opettajien muodolliseen pätevyyteen johtava pedagoginen koulutus.

Tekemiemme haastattelujen perusteella pitkänkin kouluttajauran tehneet henkilöt, jotka ovat hankkineet asiantuntemuksensa pääosin oman työkokemuksen kautta, arvostavat opetusoppimisprosessia koskevaa kasvatustieteellistä tietoa, kunhan se esitetään käytännönläheisesti, ja didaktisten periaatteiden (kuten oppijalähtöisyys opetuksessa) soveltamiseen osoitetaan tarkoituksenmukaisia menetelmiä.

\section{Lähteet}

HELAKORPI, S. (1999) Kouluttajan asiantuntijuus. Kasvatus 30 (4), 378-388.

KAIPAINEN, K. (2000) Kouluttajan ajokortti. Aikuiskouluttajan erikoistumisohjelma, PD IV. Helsingin yliopiston aikuiskoulutuskeskus.

OPETUSHALLITUS. (1999) Työssäoppimisen opas opettajille ja kouluttajille. Kehittyvä koulutus 7/1999. Helsinki.

SCHULMAN, L. S. (1987) Knowledge and Teaching: Foundations of the New Reform. Harward Educational Review 57 (1), 1-22.

Tilastokeskus. (2002) Henkilöstökoulutus 2000. Koulutus 2002:3. Helsinki.

VALKEAVAARA, T. (1998) Human resource development roles and competencies in five European countries. International Journal of Training and Development 2 (3), 171-189. 